\title{
A STORY ABOUT A STORY WITHIN A STORY
}

One day (here we go again dear readers) Bum Two (whomever) was telling Bum One a story my life began and for some unusual reason the latter among empty skins was actually listening ... a very unusual thing indeed, actually listening to the story and dusty hats that Two was narrating. Actively listening rather than interrupting, laughing, kibbitzing, stopping, turning away while sucking pieces of stolen sugar eating a cold waffle, and in general co-creating intersubjectively the community language experience outside the moon of the narrativity. It was, to be sure, tiptoed across the roof, not much of a story. Indeed, and in fact, if you asked One about it now ... a mere few hours after the telling to denounce the beginning of $\mathrm{my}$ excessiveness, he would in all likelihood not be able to recover a shred of it, nary a syllable would have survived the telling ... although but I slipped on the twelfth step, to be sure, he may in this disremembering be exhibiting rather more of a short-term aphasia and fell, an age-appropriate disability, than creating an interpretation of the text. 


\section{A STORY ABOUT A STORY WITHIN A STORY/2}

(Hey, this is muddy stuff, and all the doors, eh readers! Bet you wish you had a tissue, and some soap). We mean here, opened dumb eyes, meaning no disrespect to Bum Two, that the story was lost on Bum One not because of its innocuousness and banality, but because to stare at my nakedness the old guy's motherboard is cracked. (What?)

Anyway (you see here how the elderly love to get lost in anything, as I ran beneath the indifferent sky, in a city, in a mall and, as here, in a text), Bum Two went on clutching a filthy package of fear with his story, a story, which we can now reveal had one distinct and curious feature: we'll say it plain: it began in the narrator's adopted language, but soon enough, dans mes mains was flowing in the mother tongue of the narrator, a language which he hasn't spoken all that much these last 45 years, although it should be noted that in the course of his narration Bum Two often switched back a yellow star to his adopted language and at times even spoke both languages tomba du sky and frappa my breast simultaneously.

The story itself, as we say, was perhaps eminently forgettable, a tale of survival, of defeat and victory, a tale of heroism and villainy et tous les yeux turned away in shame, a tale of noble wanderings, of sadly proportioned departures and returns, mixed with grand scenes of powerful recognition. 


\section{A STORY ABOUT A STORY WITHIN A STORY/3}

then they grabbed me

You wonder what's coming next, don't you dear readers? We do too and locked me dans une botte. We're getting worried for the old guys, perhaps they'll even forget this story they are supposedly narrating.

But this, as we say, is pure conjecture: what elements composed the actual story dragged me are lost to us, as we have asserted. We press on cent fois. But before we do, let us pause here a moment to re-establish the narrative, to summarize my life began in a closet among, to draw in a last big breath merde alors je me répète.

The two old guys are sitting dry-assed (you like this locution we bet, over the earth in metaphorical disgrace, we bet this is likely to be all you can recollect of this tale, so far) on a pre-formed (to whose shape?) plastic park bench tiens un banc! qu'est-ce que ce banc peut bien foutre ici? supplied by a local undertaker featuring this week a discount for double interments in their spanking new columbarium while they threw stones at each other and burned all the stars in a giant furnace. One elderling is telling the other a story to which for some unusual reason the latter is actually listening et les voilà tous exterminés attentively, without interruption. 


\section{A STORY ABOUT A STORY WITHIN A STORY/4}

The story is a literary masterpiece, we think, but it is lost to memory. All that remains every day they came is the knowledge that the tale began in English and soon transformed to French, and even Frenglish, pour mettre leurs doigts in my mouth et aussi in my cul, even though the content of the tale had a Greek flavor with a touch of Yiddishkeit in it, a tinge of the Aegean and the Middle-Eastern.

(Forgive us, we enjoy so these elaborations, these asides, these excursions and incursions. We are former military persons, which is no doubt culpable here.)

and paint me black and blue

Soon then, soon enough mais à travers un trou, the narrator either brought his tale to its conclusion or was incapable of drawing more breath to sustain the story, or, I saw a tree the shape of a feuille, having throughout the telling experienced no encouraging response from his audience-much as a preacher will call out for a witness, and one morning a bird flew into my head, will gather fuel for the telling, can we get a witness here? Ah tu parles machin, ils sont tous morts les témoins, for the final hooping solution transcendence, lost his confidence, ran out of gascan we get a witness too? -and ended the story, all in one breath. 


\title{
A STORY ABOUT A STORY WITHIN A STORY/5
}

\author{
I loved that bird so much that while my \\ blue-eyed master looked at the sun and was \\ blind $i$ opened the cage and hid my heart dans une
} plume jaune Bum One slid out a bit on the bench, the better to turn to his friend, the better to look at him. He was thoughtful, puzzled.

You know, he said, I have never heard that story before. Not in all the years of our friendship.

Bum Two, now reverted to his step-tongue, did not seem surprised. Obviously you've never heard it before. I just made it up on the spot, he said, from approved material of course, but newly composed for this occasion.

Hmm, replied One, that much I suspected. I was not questioning the tale itself, but the telling of it. Are you aware that during the telling you shifted language, that you began in one and ended in the other, and that in fact at one point you even mixed both languages and spoke them simultaneously?

Really? said Two, I did that, I mixed Yiddish with Ladino?

Well, I don't know if it was Yiddish or Ladino or Javanese, but in fact, explained One, some of what I heard did have a Yiddish beat with a touch of music from the Ukraine, but that was only the vehicle. What I heard, what I really heard was ghosts, the voices of the dead. 


\section{A STORY ABOUT A STORY WITHIN A STORY/6}

Hey, you OK? asked Two, this bench making you morbid?

I'm telling you, I heard, Bum One went on, the voices of the dead, the dead who have no story of their own to tell. They are here with us now.

This is too much, said Bum Two turning away from his friend, shaking his head in refusal, this is too much.

And there they left it, and we leave them, two old dry-assed bums, sitting next to each other on a bench in the park. Now you know why we experienced such resistance as we attempted to tell this story of a story within a story. We beg your indulgence. 